\title{
Policy Innovation through the Application of E-Government: Case of Bandung Championship in Assessment Information System Program
}

\author{
Siti Alia ${ }^{1}$, Elisa Susanti ${ }^{2}$, Idah Wahidah ${ }^{3}$, Fitri Pebriani Wahyu ${ }^{4}$, and Muhammad Andi Septiadi ${ }^{5}$ \\ ${ }_{1,3,4,5}$ UIN Sunan Gunung Djati Bandung, Jl. Raya A.H. Nasution No. 105 Cibiru Kota Bandung, \\ ${ }^{2}$ Universitas Padjajaran, Jl. Raya Bandung Sumedang KM.21, Hegarmanah, Jatinangor, Kabupaten Sumedang, \\ Jawa Barat 45363
}

\begin{tabular}{|c|c|}
\hline ARTICLE INFO & ABSTRACT \\
\hline Article History: & \multirow{12}{*}{$\begin{array}{l}\text { One of the applications of e-government in Indonesia is the } \\
\text { Performance Information System implemented in the city of Bandung } \\
\text { since 2014. This e-government innovation is technology-based which } \\
\text { makes assessment instruments for leaders and the people of Bandung } \\
\text { to assess the performance of the sub-district and village heads. It's } \\
\text { just that the lack of community participation makes this application } \\
\text { not work according to its function, with qualitative research methods } \\
\text { and using the theory of the author's vision to see the readiness of the } \\
\text { apparatus and society in implementing this program. This research } \\
\text { shows that the performance of the Performance Information System } \\
\text { application has not provided the maximum expected output. The } \\
\text { not optimal Performance Information System application is due to } \\
\text { several factors. There is a need for comprehensive evaluation and } \\
\text { improvement, building intensive communication and collaboration } \\
\text { between operators and verifiers at the city government and sub- } \\
\text { district levels. }\end{array}$} \\
\hline Received : 15 July 2021 & \\
\hline Revised : 20 November 2021 & \\
\hline Accepted : 21 November 2021 & \\
\hline Available online : 15 December 2021 & \\
\hline $\begin{array}{l}\text { Authorship Contribution: } \\
\text { All authors have equal contribution } \\
\text { as the main contributors }\end{array}$ & \\
\hline Keywords: & \\
\hline Decision-making, & \\
\hline E-Government, & \\
\hline Policy Innovation, & \\
\hline Readiness, & \\
\hline Performance Information System & \\
\hline
\end{tabular}

\section{INTRODUCTION}

Accelerating changes to the service system since 1990 has become something that the Indonesian government and the world have done which is now reaching the Government stage. Launching e-government projects in every service is a must for government and private companies worldwide across the globe. There are several definitions of e-government which say that one of the essential elements in e-government is website construction

\footnotetext{
* Corresponding Author.

E-mail: aliaalya267@uinsgd.ac.id; elisa.susanti@unpad.ac.id2, iddah@uinsgd.ac.id3, fitriFISIP11@uinsgd.ac.id4, Septiadi. andi90@uinsgd.ac.id5
}

and management (Torres et al., 2005). With good website construction and management, it is believed that the use of e-government has an opportunity to create a process. Service becomes better and increased community participation in using services (Schedler \& Summermatter, 2007). Today many developing countries make good contributions, many of which have started by improving the national information infrastructure and creating a safe environment for advances in information technology and technology (Walston \& Stevens, 2002). Technological development is an important feature in today's era. Every development can change our lives to some extent. 
It's just that a certain development, especially the internet, which makes an e-government innovation with the greatest potential for the massive continuation of the system that will run on local and global communities (Maugis et al., 2005).

It is hoped that the acceptance of the applied technology can be well managed by service managers and used properly by service users. Ease of accessibility and attractive content can increase people's perceptions of using these services (Haryani, 2016). However, there is no definite evidence that the positive correlation between manager readiness and user readiness can run well in a sustainable manner (Bisma, 2017; Gusman, 2018). Leaders may have high hopes for the successful application of information technology, as discussed in Coursey \& Norris (2008).

Indonesia is one of the developing countries active in implementing e-government programs (Darmawan, 2018; Ella \& Utami, 2017; Vergien \& Marta, 2016). Of the many e-government activities in Indonesia, further research is needed on the readiness of managers and users. The preparation of e-government starts from establishing a vision and guidelines for the preparation of strategic actions (Yudhisthira \& Nugroho, 2014). It also needs to be emphasized that the implementation of e-government is based on non-technology goals and objectives, which will be replaced by technology-based services and will be implemented at different levels. More concretely, we can target the use of changing non-technological services into technology-based services (Fukuda, 2020). e-government reforms can be categorized into three main areas: a) improved public services, b) increased transparency and c) wider economic and social benefits (Sipahutar, 2016).

One of the e-government implementation policy innovations in Indonesia is the Assessment Information System (AIS) implemented in the city of Bandung since 2014. This e-government innovation is technology-based which created an assessment instrument for leaders and the people of Bandung City to assess the performance of sub-district heads and village heads in their area. It is hoped that an assessment system like this can motivate the sub-district and village heads to improve the performance of their respective regions so that theoretically, it will facilitate improved management in decision making; both performance and supervision.

An assessment team can assess this SIP from the selected Bandung city assessment team, and the community can participate in this performance assessment. It's just that the community's assessment of the performance of sub-district and village officials is lacking (Sagita, 2016). This raises a question for us, whether the system built by the city of Bandung is not ready to be used by the community or users so that there is a lack of community participation and innovation in its application system. The Bandung City Government planned a policy that will be used as a legal basis in providing development and maintenance budgets as a reinforcement for program sustainability, namely in the form of mayoral regulation number 1354 of 2014 and the Mayor's decision as to the basis for the determination of the secretarial team formation and its duties.

As for previous research that examines the Bandung Assessment Information System, the champion analyzes more in terms of application branding communication, Application Utilization, and the influence of Applications on State Apparatus Performance (Hidayah, 2018; Romli \& Romli, 2020; Sagita, 2017), In this study we examine from a different point of view from previous research and using different theories, we emphasize the extent to which social networks and organizations can accept innovation, both readiness for non-technology transfer to technology and readiness from managers and users and explain how policy innovation can support decision making for leaders on village performance. In this context, there is a need to build a readiness plan to organize and take the initiative in implementing e-government in a model that includes broader and clearer development themes (Viscusi et al., 2010a).

The theory used in this study uses the theory of vision, which is analyzed based on social (community) and organization (apparatus) where the readiness indicator is based on a complex map of community potential, which will be the main factor, namely 1. physical access to ICT (e.g., civil servants), 2. the suitability and affordability 
of ICT, 3. the use of ICT in business (e.g., suppliers), 4. ICT capacity and training of civil servants, and 5. The legal and regulatory environment for using ICTs (Viscusi et al., 2010b, 2010c).

This study aims to determine the implementation of the employee appraisal system program (e-government), and iis hoped that from this research, something new will be found which will later have an impact on the sustainability of the program in a better direction and to form a policy innovation in a more effective and efficient information management system. Then it is concluded whether this program is feasible to be implemented based on the readiness of managers (regional officials) and users (community, assessment team).

\section{METHODS}

This research included the positivist research paradigm and uses a survey research strategy (Yuliansyah, 2016). Because the aim is to see that e-government can maintain transparent governance and accountability and explain the readiness of managers, users based on the characteristics that have been determined in Figure 1. This study assumes that top-level executives, managers, and users are sources of information to provide the necessary data.

The data for this study were collected from 8 villages and sub-districts in the city of Bandung using purposive sampling (Setia, 2016), where the selection is emphasized on areas that are often considered the least ready and most ready to use the e-government system.

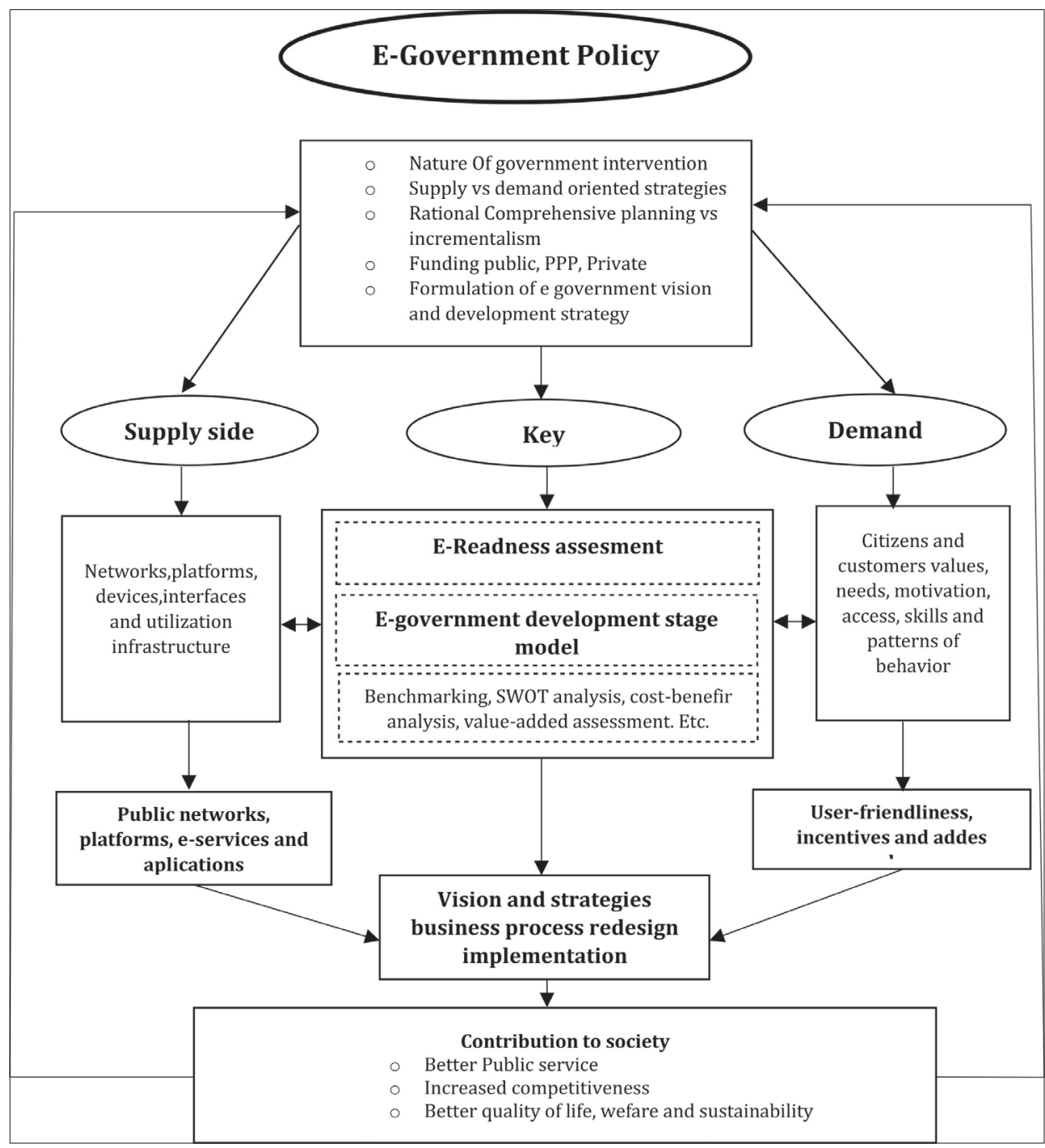

Figure 1. Models of e-government policymaking to the extent that they can contribute to society 
With a qualitative approach (Sugiyono, 2013), researchers trace the development of the application of e-Government, namely the Employee Assessment System assisted by triangulation techniques (Rahardjo, 2010). The theory used the theory of vision, which the researcher describes in Figure 1.

To obtain the data, we used a literature study from Hart (1998) where we found important variables relevant to the theme, synthesized and gained new perspectives, identified the relationship between ideas and practices, defined the context of the topic or problem, rationalized the importance of the problem, added and acquired the vocabulary of the subject, understand the structure of the subject, relate ideas and theories to applications, identify key methodologies and research, and place research in context to demonstrate research developments.

Using the theory of readiness from Viscusi et.al (2010a), the data obtained are loaded into several memos based on the theory of Corbin and Strauss (2014), where we organized the evolving understanding of the data and created useful memos. To describe what we have learned, where the results will be classified into several themes and select data related to the research. After that we used the analysis matrix of Miles and Huberman (1994) to get a broad view of the data, which helps identify patterns in the entire data set and ultimately described qualitatively (Creswell 1994). The three main findings became the focus of research were user readiness, and how this application can assist the central government in making district/kelurahan performance decisions.

\section{RESULT AND DISCUSSION}

In the city of Bandung, there is PP No. 185 of 2015 concerning the handover of a portion of the Mayor's work to the sub-district head and the village head because of the need for a policy direction that leads to the role of the region. Clean and open government, in the context of realizing government transparency and accountability. Performance Information System is one of the programs initiated by the Mayor of Bandung, Ridwan Kamil in the period of 2013-2018 so that the Bandung City government has a special assessment system that uses information technology where the final result can be measured

\section{Table 1.}

Ranks of the Results of the Performance Evaluation of Heads of Sub-Districts and Urban village in the Bandung City Government in 2018

\begin{tabular}{|c|c|c|c|c|c|}
\hline No & Sub-district & $\begin{array}{l}\text { Assessment } \\
\text { Index }\end{array}$ & No & Sub-district & $\begin{array}{c}\text { Assessment } \\
\text { Index }\end{array}$ \\
\hline 1. & Lengkong & 98.28 & 16. & Astana Anyar & 90.68 \\
\hline 2. & Batununggal & 97.93 & 17. & Cibeunying Kaler & 90.62 \\
\hline 3. & Mandalajati & 97.41 & 18. & Cidadap & 90.12 \\
\hline 4. & Panyileukan & 94.91 & 19. & Sukasari & 89.78 \\
\hline 5. & Sukajadi & 94.85 & 20. & Sumur Bandung & 89.71 \\
\hline 6. & Babakan Ciparay & 93.78 & 21. & Cibeunying Kidul & 89.15 \\
\hline 7. & Cicendo & 92.85 & 22. & Kiaracondong & 88.38 \\
\hline 8. & Ujung Berung & 92.65 & 23. & Buah Batu & 88.18 \\
\hline 9. & Rancasari & 92.13 & 24. & Bojongloa Kaler & 87.44 \\
\hline 10. & Bojongloa Kidul & 91.87 & 25. & Arcamanik & 86.84 \\
\hline 11. & Cinambo & 91.31 & 26. & Bandung Kulon & 86.06 \\
\hline 12. & Antapani & 91.26 & 27. & Bandung Wetan & 85.52 \\
\hline 13. & Gedebage & 91.19 & 28. & Bandung Kidul & 84,88 \\
\hline 14. & Cibiru & 91.09 & 29. & Andir & 82,25 \\
\hline 15. & Coblong & 90.92 & 30. & Regol & 75,71 \\
\hline
\end{tabular}

Source: Bandung City Regional Secretariat General Government Section, 2018 
quantitatively concerning the performance of the Head of Sub-district and Head of the Village.

This system aims to provide a direct assessment of the performance of regional officials in particular to improve prime public service to citizens. Where sub-districts are the extensions of the Mayor, who must take care of the Mayor's authority part. The Performance Information System, Bandung Champion program, is strengthened by the legal basis of the Bandung Mayor's Regulation on Procedures for Evaluating the Performance of Heads of Sub-Districts and Urban village head Number 036 of 2019, which has been revised from Mayor Regulation No.1354 of 2014 due to the need for adjustments in its development. The assessment indicators in the Performance Information System include the administration of general government affairs, the administration of sub-district services, the implementation of other tasks assigned to the subdistrict head, the sub-district innovation and efforts made by the sub-district, and the subdistrict profile (the existence of other supporting data).

Based on the results of data collection in the field (Table 1), discussions were carried out based on the e-Readiness theory put forward by Viscusi et al (2010b), which states that E-Readiness refers to the extent to which social networks and organizations are ready to accept innovations made possible by Information and Communication Technology. In the processes it is involved in and how readily it is to take advantage of digitization. In other words, it determines how existing policies and practices and institutional frameworks support the adoption of a sustainable e-government system.

Measuring e-government readiness presents many methodologies which combine the socioeconomic context, and can be an added value to measure the readiness to use e-government. The e-government framework (Viscusi et al., 2010b) considers how information technology affects organizations and how the social and organizational context affects the use of technology. In this context, there is a need to build a new readiness methodology, which can organize egovernment implementation initiatives in a model that includes a broader and clearer development theme. This research uses the e-Readiness theory (Viscusi et al., 2010b) with the dimensions of Organizational units, Socio-Economic Context, ICT Access and Diffusion, Analysis of the users' Analysis of The Service.

\section{A. Organizational Units}

Organizational units where the main indicators are Organizational Structure, Administrative Processes, Resources, and Learning Related to Information Technology. This dimension is used to measure the extent to which regional parties organize and intervene in the implementation of Performance Information System Bandung Champion, starting from the organizational structure to training facilities for the Performance Information System Bandung Champion human resources program.

The organizational structure is used to support functions and assign staff to these functions (Heeks, 2005). The Performance Information System (SIP Bandung Juara) has a decentralized structure. In his book Heeks (2005), decentralized e-government systems is a decision taken at a lower level than the most senior, usually by individual work units within the organization or even by individual staff. Decentralization in the e-government system is a decision taken at a lower level than the most senior, usually by individual work units or even by individual staff. This is supported by the opinion of Galvan (2019) that it is impossible to manage a large organization with a small number of staff, which makes the assignment of functions complicated. Departments should be expanded spontaneously and improvised by involving an integrated management information system. The latter can also be referred to as end-user computing. The individuals in the public sector who use the outputs of the e-government system (internal end-users) are also those who operate, develop, and manage the system.

According to the Head of Subdivision of General Personnel in Arcamanik District, Mrs. Mega Fajrina, that decentralization in the SIP system exists because there is a delegation of some of the authority from the Mayor to the Camat, 
and there are five sections that carry out service activities, namely, the government section, the peace and order section, the social welfare section, the economic development section and the community empowerment section.

When talking about vertical coordination, namely the relationship between the sub-district and the Bandung City Government, it can be seen that coordination is quite good. Still, if we talk about technology-based developments, it seems that there are several obstacles. For example, in the implementation of Performance Information System, because the Performance Information System application is made by the Bandung City Government and is directly managed centrally, so the development that the sub-district can do is only in the form of changing the profile because regional parties only carry out what is provided by the Bandung City Government. It can be said Regional parties are only users of the Performance Information System application who are required to report their performance which will later be assessed by the team in the Bandung City Government.

One of the features in Performance Information System is the innovation feature. This feature is used if there is an application or activity initiated by the sub-district/village and is a breakthrough for the community's needs. This innovation can be made if no similar innovation has been launched and must pass a study from the Bandung City Communication and Information Service (Diskominfo) and must be under the Mayor's vision and mission. In the production of services and products, innovation is expected to improve performance (Lu et al., 2020; Sururi, 2017).

Through this application, it is hoped that it can be used as a tool to become the right means for villages to provide information on development programs and community empowerment (Gatara et al., 2021). With this application, it is easier for the community to assess and evaluate the programs that are made, so this application is very appropriate to be implemented amidst the community's needs to see the performance of their leaders and serve as a means of public accountability for the village.
For Administrative Process indicators using Performance Information System administratively, each District must report their performance into different parts regularly, namely monthly and incidentally. The sub-district admits that this application is quite easy to use to avoid being confused whilst using it. Therefore, in routine performance reporting, these are familiar with the Standard Operational Procedure (SOP) because they already know the procedure and the monthly reporting process. Then for incidental reporting, SOPs have been running coupled with stronger coordination.

In terms of operating the Performance Information System, the District Party does not find it difficult to run it because the systematization is quite easy. However, there are several shortcomings in this application, namely:

\section{B. Collecting data from related fields}

The data is not all delivered on time, and most data managers have to pick up the ball to hampers other parts. The data manager is in charge of collecting data and processing data. If there is invalid data or missing data, a data processor will correct it in the relevant section.

\section{Data is not updated and less accurate}

Data processors must be careful and selective in processing data. If there is data that is not updated or inaccurate, then it is considered data manipulation and will reduce the Assessment of the District.

There are various forms of service to the community, one of which is population administration service and security, order, and cleanliness services such as community protection, all of which are regulated and under the coordination of the sub-district. Apart from being a service provider, the sub-district is also the implementer. For example, if the leadership needs data on the poor who cannot receive assistance, then the subdistrict will go to the field to collect data. If the sub-district head needs a report on the number of tower construction in the sub-district area, it will be coordinated, and within 3 days the report is already available. 


\section{Human Resources/ICT Related Learning}

For indicators of training facilities for Human Resources (HR) / ICT Related Learning programs, the Performance Information System Bandung Champion, based on the results of field observations, it is admitted that there has been no socialization to the operator and verifier levels of the Performance Information System Bandung application. Champion in sub-districts and wards, in terms of quantity and quality, is also still inadequate. Based on data in the field, each subdistrict has prepared two experts in informatics who are assigned to manage data and information as operators and verifiers in the sub-districts, according to Law no. 13 of 2003 job training. Training facilities for human resources, especially for application operators, are deemed very important to improve the quality of their performance and increase the level of skills, especially skills in managing information technology-based applications (Brewster \& Söderström, 2017). In addition to training on skills, according to (Guterresa et al., 2020), personality training is needed for an organization as a foundation because leaders and employees drive the wheels of the organization.

Employee training is very important because technological developments require that many organizations must be able to adapt through human resources or employee capacity (Rahman et al., 2020). The Performance Information System application changes the pattern of relations that are built between the government and the community. The most important thing is the readiness of the institution, in this case, the Village / Kelurahan. Many organizations have implemented digital transformation but have failed due to suboptimal HR support. Identifying the need to build the right strategy in implementing SIP applications is very important. Therefore it requires a large investment in addition to the platform and human resources through training (Kaul, 1997).

But in fact, the application is only socialized to the sub-district head through Mayor Regulation Number 036 of 2019 concerning Procedures for Evaluating the Performance of Heads of SubDistricts and Urban village head, which includes procedures for reporting performance electroni- cally through the performance information system Bandung Championship application. Then from the sub-district head instructed his subordinates to be disseminated to the Urban village, so for the existence of training related to Performance Information System itself, there was no training given specifically to regional parties, especially for operators and verifiers in the District and Urban village.

No less important is the fact that training, technology-based socialization is provided to the community. People are interested in using applications available in the sub-district to support services even though services can be done online. There is also an assessment feature from the community on the applicable Performance Information System. It turns out that many people are reluctant to use it or cannot because they do not know that this application exists because of the low knowledge they have and the lack of socialization to the public regarding the existence of this Assessment Information System program.

\section{E. Socio Economic Context}

The Socio-Economic Context aspects consist of Socio-demographic context and infrastructural access. Based on an interview with the Head of the Public Administration who oversees the Territorial, Sub-district and Urban village sectors in Bandung City, when viewed in terms of the condition of the internet network, for internal purposes, the sub-district itself is sufficient, and also has good infrastructure and can support based public services, because there are hotspots that operate for 24 hours. This hotspot is a gift from the Bandung City Information and Communication Office, which previously collaborated with PT. Telkom Indonesia, with the facts above, actually in terms of internet connection is very maximal, but only for the internal District cannot be used by the surrounding community for free. The facilities for Personal Computers, printers, scanners as supporting facilities in the use of applications are sufficient and supportive, each Performance Information System management operator has its own Personal Computer, printer, scanner and is connected to the internet network, as well as for other employees Personal Computer 
facilities, printers, scanners. It is not a rare item in the District Office in Bandung City to support the performance of its employees.

However, if viewed from an external perspective, the District in Bandung City has not been entirely successful in pursuing a digitalization movement in its environment, in particular increasing public knowledge and participation in applications launched by the Bandung City government as well as several government programs that require fairly high community participation such as Serial Tapis Program (Asmaria et al., 2020). As quoted from $\mathrm{Fu}$ (2021) that environmental digitization requires combining computer information technology with specific environmental analysis, using modern environmental science theories and methods to protect the environment in a planned manner.

Analyzing requirements is the first step in making an organization's decision to implement a SIP application. Environmental analysis is fundamental and is used as a source of identification of community readiness so that people are required to expose themselves in the face of new dynamics, namely digital transformation (Fukuda, 2020). The SIP application indirectly becomes a choice that benefits the information technology process and instructs the public to adapt in the digital era (Wuryanta, 2004).

Based on this information, the social and economic conditions in each sub-district in Bandung City are different. There may be people who already have adequate internet network facilities and make internet network one of the necessities so that it is available 24 hours in their respective homes. And on average, they are residents of a lower economic class. However, some have not made the internet a basic necessity because, from an economic perspective, they are still very weak. To pay for their daily lives is still difficult. This is certainly homework for the Bandung City government, especially regional officials, to deal with this situation so that efforts are made to have an easy and cheap internet network that all levels of society can use.

Since 2014, the Bandung City Government has been working on the existence of Bandung Champion Wi-Fi which is placed in 149 central points of the crowd in the city of Bandung, even in every sub-district, places of worship, parks, sports facilities in the city of Bandung installed Wi-Fi Bandung Champion which can be accessed free of charge by the wider community, but it was reported (Fahmi, nd) since March 1, 2020, the Bandung Wi-Fi Champion could no longer be accessed, the editorial team from PRFM tried to clarify this to the Bandung City Information and Communication Office via Direct Message on social media. According to him, the media of Diskominfo Bandung, according to him, is currently carrying out the process of migration and replacement of internet services which have an impact on the Bandung champion's Wi-Fi access network cannot be used. Hopefully, shortly, the Bandung Champion Wi-Fi can be accessed again by the people of Bandung City, to make it easier for all levels of society in Bandung to be connected to the internet, so that applications issued by the Bandung City Government increase the level of community participation and the benefits can be felt properly by society at large.

Also, the factors that hamper the running of the Performance Information System program for the community are weak education, age factors, technology stuttering, and daily activities that are mostly spent outside, so filling out Performance Information System by the community has not become a top priority for them. A minimum level of infrastructure, education, supportive government policies must be in place for a country to benefit from ICT (CID, 2016).

The above also relates to the dimensions of ICT Access and Diffusion to see how often people access and their knowledge of the applications issued by the City Government of Bandung, especially the application of this Performance Information System. According to the author's observations in 8 districts in Bandung, four districts with the best ratings include Mandalajati District, Rancasari District, Cinambo District, and Panyileukan District. And four Districts with the lowest ratings, including Gedebage District, Arcamanik District, Antapani District, and Buah Batu District.

The authors conducted interviews with 20 residents around the sub-district from each of 
these districts from each sub-district. It turned out that the result was that, on average, they did not know the Bandung Performance Information System application, as well as government services that could be accessed online. There were only four of the 20 informants who know about the application. Even then, they are active in community activities, such as RW and members of the Youth Organization. At the same time, others do not know of the existence of socialization from the District or Urban village regarding the application and online services in the District or Urban village. They are more interested in coming in person if there is a demographic administration need than accessing it online. They don't even try to find out, because according to them, the services provided by the District or the Urban village are good enough compared to previous years.

From this, of course, the authors can draw the conclusion that there is a need for increased socialization from regional parties, especially the District, assisted by Urban village, Hamlet, and Neighbourhood to the community regarding the importance of community participation in online services, especially in the Bandung Champion SIP application. Today's public institutions are pressured to innovate, pushing service delivery toward a more personal, participatory, efficient, and collaborative model. In this sense, social media and applications can be powerful potential tools to encourage public engagement, which aims to improve public services and form relationships between government and citizens based on information exchange and dialogue (Bolívar, 2016; Gao \& Lee, 2017).

There needs to be a special program to socialize the Performance Information System application to the public. Socialization is carried out as a strategy to provide information to the public regarding the existence of the SIP application, which aims to assess performance. The role of the community is very important to take part in providing performance appraisals or evaluations. (Putra, 2020) The higher community participation in using the SIP application indicates that the application is the right medium for interaction between the government and the community. Apart from that, it is necessary future innovation policy designs can build on 'creative corporatism (Kuhlmann \& Rip, 2018).

Given the lack of public knowledge about the programs implemented by the sub-district, this can be a factor in whether or not a governmentrun program can also be seen through the workreadiness equation model (Pusp \& Permatasari, 2020). With interesting socialization, it can help increase community participation in programs issued by the government. Socialization is very important because, with the socialization process, a person can interact between individuals, groups with groups, groups with individuals, in this case, the government and the community. Programs that are being implemented and those that have been implemented need to be socialized to the community to ensure that the program can be run well and receive community support. Furthermore, the program, from understanding the community to complying with and helping the program, is a domain of public policy studies (Herdiana, 2018).

Without a perfect socialization process, interactions will not run well, programs/policies made by the government for the benefit of the community will be in vain because there is no support from the community due to the lack of public knowledge of the programs/policies launched by the government. Also society tends to do things that violate the norms and rules that apply in society, which will have a bad effect on the relationship between the government and society, gaps can even occur when people rebel against the government, for example, if there are policies that are not relevant to the government and society-community conditions and not socialized

\section{F. Analysis of The Service}

The next dimension of the e-readiness theory (Viscusi et al., 2010b) is an analysis of the service. The authors analyzed what services were provided to the community offline and online. Services in sub-districts Bandung City that are already online are grouped into several categories. Among them are e-government in personnel management, e-government in the service sector, e-government in the budget sector, e-government 
in the field of planning, e-government, etc. As for e-government for services to the community based on electronics, the sub-district is only an extension of the related agencies, so the task of the sub-district is only to provide reports related to activities that have been carried out.

The online services available to the community organized by the city government of Bandung include SIP (Performance Information System), E-Posyandu, E-Satria, United Nations Service Information System (SIP PBB), Electronic Performance Remuneration System (E-RK), SARING (Negative Information Reporting) and GAMPIL (Gadget Application Mobile for License).

Data, the internet, smartphones, and mobility are changing the relationship between policymakers and society. Easier access to information provided by governments and the ability to access and analyze information in real-time have brought many governments closer to their citizens. This has positive benefits in terms of improved governance, efficiency, and participation. However, on the other hand, Governments and citizens are facing increasing risks and challenges from cybersecurity and cybercrime. Issues around the lawful use of data, threats to the disclosure of personal information, and the task of coordinating cross-jurisdictional policies and approaches (Falk et al., 2004).

In addition to programs designed online, the city government of Bandung also organizes program activities that require direct community participation, namely: Kangpisman (Reduce, separate, utilize), Bandung City Development Planning Deliberation Program (Musrenbang) 2020, The Garbage Pungut Movement (GPS).

Then, in the work process in sub-districts and Urban villages in Bandung City, IT, especially in SIP, is very helpful in reporting activities in the sub-district/Urban village and decision making for the central government.

But, in its implementation, the Performance Information System is still lacking. Sub-optimal because not all performance in the sub-district/ Urban village is reported to Performance Information System. This happens because many activities are not accommodated in Performance
Information System, and many routines must be carried out, which results in the SIP assessment being unable to be carried out as a whole. As in Yusifov \& Gurbanli (2018), it is better if the information system application that is made can evaluate at least by considering three criteria, namely the level of digitization and relevance, the level of openness, and accessibility of information, and the level of convenience of use. It's just that the current SIP application is still not included in these criteria because there is still a lack of accessibility and relevance of information, making it difficult for urban villages to fill in the performance of the application.

The lack of accessibility and relevance of information is an obstacle for SIP not running optimally, and its usefulness is not felt. There needs to be a strategy for how to build the accessibility and relevance of information. The District's difficulty in filling out applications is evidence that Performance Information System has not been implemented properly. Accessibility improvements can be made through training or simplification of the system. At the same time, it is necessary to pay attention to the application guidelines and build a common perception (Kong et al., 2018).

\section{G. Analysis of the Users}

The last dimension of e-readiness from (Viscusi, Batini, and Mecella 2010) is an analysis of the users by looking at the condition of the surrounding community in Bandung, starting from gender, age, educational background, occupation, and their daily activities. Do more, whether around the house or outside the house. This is useful to see how the characteristics of the community, especially those around the city of Bandung, respond to all forms of online services provided by the Bandung City Government to provide more effective and efficient public services for their citizens. Are people ready for all forms of online services, ready in terms of their devices, the knowledge of using smartphones and accessing applications, and whether connectivity with the internet has become a basic requirement for them and is always connected $24 / 7$. 
All online services provided by the government are focused on the benefits provided. For these benefits to be felt directly by the general public and the application of online-based service applications need to run effectively. It is necessary to know the extent to which an online service application is accepted and the success of an online service application. Using De lone and Mclane's model aimed to identify and assess the success of an information system (Purwati et al., 2021).

Acceptance of an application is the main key in initiating an application and can contribute to the success index (Fukuda, 2020). In this case, the government needs to assume the community's response and how much the application benefits the community. The importance of identifying the needs and expectations of the community is carried out so that the application is right to answer community demands. This model's impacts were measured user satisfaction and the desire to use an information system, in this case, the implementation of the Performance Information System. The dimensions of this model were information quality, system quality, and service quality.

1) Information quality, related to the characteristics of the output produced. Based on the observations in several sub-districts of Bandung City, one of which is the Cinambo sub-district, there was low community participation in the Performance Information System program because there has been no socialization from the village to the neighborhood and Hamlet. The information provided was not updated, so they don't know how the Performance Information System functioned. However, for other programs such as cooperation, eating with the poor, etc., which are manual, these have been running well, and community participation has also been good. This showed that providing clear and precise information was very influential on the use of the Performance Information System program.

2) System quality related to the characteristics of the information system used, such as the ease of learning and using the system. Several factors affect the level of ease of information systems that the general public can accept, including age, education, environment, and culture, not all people can use it. Even operating the information service system, the presented service system must be made effective and efficient.

3) Service quality relating to the quality of service received by users from the system used. Based on the observations from several subdistricts, including Buah Batu, Arcamanik, and Cinambo sub-districts. The community complained about the services received was a convoluted bureaucratic process, the lack of transparency, and the difficulty of accessing online services both technical and non-technical constraints. This phenomenon, although common, must be of particular concern to related parties so that government programs such Performance Information System can be used and provide sustainable benefits for the entire community.

\section{H. The readiness of Employee Information System Program (SIP) Bandung Champion}

The readiness of the Performance Information System program is based on analysis using the theory of Viscusi, Batini, and Mecella related to the dimensions of Organizational Units related to organizational structure, administrative processes, resources, and learning related to technology were not optimal considering vertical coordination has been quite well established. However, there are still obstacles in terms of aspects. Technologybased development, in this case, the implementation of Performance Information System, which is managed centrally, resulted in limited access used at operators and sub-districts levels. There has been no socialization to the operator and verifier levels of the sub-districts and villages. Based on the Socio-Economic Context dimension, seen from the Socio-demographic context, the City of Bandung has not maximally sought the digitalization movement to affect the level of community participation. Besides that, the infrastructure access of the Bandung city government has provided wifi facilities that were accessed for free from 149 points. However, there were 
obstacles that were difficult for people to access due to the alternation of internet services. Based on the dimensions of ICT Access and Diffusion, it is not optimal because there are still many who do not know the Bandung Performance Information System application, as well as government services that can be accessed online and have an effect on the level of effectiveness of the Performance Information System program. The next dimension relates to the analysis of the service provided that has adapted to the use of technology with innovative programs in the face of the industrial revolution era 4.0, or the digital era, where the government is required to provide services to the community more effectively and efficiently. The last dimension relates to the analysis of the users influenced by information quality. The community has not updated information related to Performance Information System because there is no socialization, so that it had little impact on the community's ignorance of the Performance Information System program. The quality system still needs to be simplified so that it is easy for users, who are quite diverse in terms of age, education, and cultural environment. System quality still needs to be given more attention to service quality so that it is more effective and efficient and less complicated, more transparent and reduces the level of difficulty in accessing online services.

Even so, Performance Information System is an integrated system of the Bandung city government in conducting performance assessments of villages and sub-districts, where innovation in personnel management policies is enough to help the central government (Bandung City) in making decisions related to the performance of subdistricts and sub-districts rather than assessing prior to the existence of an integrated personnel management system.

\section{CONCLUSION}

Technology-based e-government policy innovation to assess the performance of District and sub-district, namely the Performance Information System, is expected to motivate Head of District and Head of sub-district to improve performance. This program is important to implement because it involves the instruments of the people of Bandung to be involved in providing an assessment of the leader performance. However, the performance of the Performance Information System application has not provided the maximum expected output. The Performance Information System implementation is not yet optimal due to several factors.

It is necessary to have a comprehensive evaluation and improvement, build intensive communication and collaboration between operators and verifiers at the City Government and sub-district levels, improve program support facilities, and maximize support and synergy from all sub-districts and villages to increase program optimization. One of the factors causing the slow pace of this program is community participation. There was no program socialization, which impacts public ignorance and the need for digitalization efforts to encourage people from various circles to participate. The leadership and commitment of mayors, sub-district heads, and village heads can accelerate the development of the Performance Information System program. In the context of developing Performance Information System management capacity, a special approach is needed, especially to open up understanding and perceptions of the importance of community involvement in assessing the performance of their regional leaders based on trust and transparency. In addition, the development of community-based policy innovation is a new direction for e-government. It was seen that the application of an integrated system can facilitate the central government (Bandung City) in monitoring and making decisions on employee performance.

\section{REFERENCES}

Asmaria, A., Dewi, L. K., \& Akbar, M. F. (2020). Tingkat Partisipasi Masyarakat Terhadap Program Pembangunan Gemma Tapis Berseri Di Kecamatan Kedaton Kota Bandar Lampung. Khazanah Sosial, 2(1), 1-14.

Bisma, R. (2017). Faktor Adopsi Layanan E-Government Jenis Layanan Transaksi. JIEET (Journal of Information Engineering and Educational Technology), 1(2), 83-88. 
Bolívar, M. P. R. (2016). Policymakers' perceptions on the citizen participation and knowledge sharing in public sector delivery. In Social media and local governments (pp. 37-56). Springer.

Brewster, C., \& Söderström, M. (2017). Human resources and line management 1. In Policy and practice in European human resource management (pp. 51-67). Routledge.

CID. (2016). readiness for the network world-guide for developing countries. www.readinessguide. com

Falk, S., Römmele, A., \& Silverman, M. (2004). Digital Government: Leveraging Innovation to Improve Public Sector Performance and Outcomes for Citizens. Springer.

Fu, X. (2021). The Application of Computer Information Technology in Environmental Analysis. 2020 International Conference on Data Processing Techniques and Applications for Cyber-Physical Systems, 147-153.

Fukuda, K. (2020). Science, technology and innovation ecosystem transformation toward society 5.0. International Journal of Production Economics, 220, 107460.

Galvan, I. P. (2019). Designing Local E-government: The Pillars of Organizational Structure. Emerald Group Publishing.

Gao, X., \& Lee, J. (2017). E-government services and social media adoption: Experience of small local governments in Nebraska state. Government Information Quarterly, 34(4), 627-634.

Gatara, A. A. S., Susanti, E., Septiadi, M. A., Alia, S., \& Wahyu, F. P. (2021). Efforts to increase public participation in assessment information systems use User-Centered Design. IOP Conference Series: Materials Science and Engineering, 1098(3), 32024.

Gusman, D. (2018). Analisis Kesiapan Infrastruktur Teknologi Informasi Dalam Mewujudkan E-Government. Jurnal Inovasi Teknik Informatika, 1(1), 20-28.

Guterresa, L., Armanu, A., \& Rofiaty, R. (2020). The role of work motivation as a mediator on the influence of education-training and leadership style on employee performance. Management Science Letters, 10(7), 1497-1504.

Haryani, P. (2016). Evaluasi Kualitas Layanan E-Government Pemerintah Kota Yogyakarta Dengan Metode E-GovQual Modifikasi.

Herdiana, D. (2018). Sosialisasi Kebijakan Publik: Pengertian dan Konsep Dasar. JURNAL ILMIAH WAWASAN INSAN AKADEMIK, 1, 13-26.
Hidayah, I. (2018). Pengaruh penerapan aplikasi Sistem Informasi Penilaian (SIP) Bandung Juara dalam meningkatkan kinerja camat dan lurah Kota Bandung tahun 2016-2017. UIN Sunan Gunung Djati Bandung.

Kaul, M. (1997). The new public administration: management innovations in government. Public Administration and Development: The International Journal of Management Research and Practice, 17(1), 13-26.

Kong, D., Lin, C., Wei, L., \& Zhang, J. (2018). Information Accessibility and Corporate Innovation. Available at SSRN 3291811.

Kuhlmann, S., \& Rip, A. (2018). Next-generation innovation policy and grand challenges. Science and Public Policy, 45(4), 448-454.

Lu, W., Wang, H., Lin, Y., \& Li, L. (2020). Psychological status of medical workforce during the COVID-19 pandemic: A cross-sectional study. Psychiatry Research, 288, 112936.

Maugis, V., Choucri, N., Madnick, S. E., Siegel, M. D., Gillett, S. E., Haghseta, F., Zhu, H., \& Best, M. L. (2005). Global e-readiness-for what? Readiness for e-banking. Information Technology for Development, 11(4), 313-342.

Purwati, A. A., Mustafa, Z., \& Deli, M. M. (2021). Management Information System in Evaluation of BCA Mobile Banking Using DeLone and McLean Model. Journal of Applied Engineering and Technological Science (JAETS), 2(2), 70-77.

Pusp, R. C., \& Permatasari, Y. R. (2020). Model Persamaan Struktural Dalam Meneliti Pengaruh Keaktifan Organisasi Dan Prestasi Belajar Terhadap Kesiapan Kerja. Khazanah Sosial, 2(2), 94-104.

Putra, J. M. (2020). Strategi Komunikasi Dinas Kependudukan dan Pencatatan Sipil Kota Bandung dalam Sosialisasi Aplikasi Salaman k epada Masyarakat Kota Bandung. UNIKOM.

Rahardjo, M. (2010). Triangulasi dalam penelitian kualitatif.

Rahman, M., Mustari, N., Novitasari, N., \& Atirah, S. (2020). E-Goverment Based Education Policy Innovation Through E-Panrita Applications (online Attendance Study For Teacher at SMAN 3 Luwu). Journal of Local Government Issues (LOGOS), 3(1), 50-63.

Romli, R., \& Romli, N. A. (2020). Implementasi strategi komunikasi "Bandung Juara" sebagai bagian dari city branding Kota Bandung. PRofesi Humas, 4(2), 263-289. 
Sagita, N. I. (2017). Pemanfaatan Teknologi Informasi Dalam Penilaian Kinerja Kecamatan Dan Kelurahan Di Kota BANDUNG. JIPAGS (Journal of Indonesian Public Administration and Governance Studies), 1(2).

Schedler, K., \& Summermatter, L. (2007). Customer orientation in electronic government: Motives and effects. Government Information Quarterly, 24(2), 291-311.

Setia, M. S. (2016). Methodology series module 5: Sampling strategies. Indian Journal of Dermatology, 61(5), 505.

Sugiyono. (2013). Metode Penelitian Pendidikan Pendekatan Kauntitatif, kualitatif dan R\&D. Alfabeta.

Sururi, A. (2017). Inovasi Kebijakan dalam Perspektif Administrasi Publik Menuju Terwujudnya Good Public Policy Governance. Spirit Publik: Jurnal Administrasi Publik, 12(2), 14-31.

Torres, L., Pina, V., \& Acerete, B. (2005). E-government developments on delivering public services among EU cities. Government Information Quarterly, 22(2), 217-238.
Viscusi, G., Batini, C., \& Mecella, M. (2010a). eReadiness Assessment. In Information Systems for eGovernment (pp. 99-125). Springer.

Viscusi, G., Batini, C., \& Mecella, M. (2010b). Information systems for eGovernment: A qualityof-service perspective. Springer Science \& Business Media.

Viscusi, G., Batini, C., \& Mecella, M. (2010c). The different facets of e-government initiatives: paradigms and approaches. In Information Systems for eGovernment (pp. 3-19). Springer.

Walston, V. J., \& Stevens, R. J. (2002). AfricanAmerican Experience in World Mission: A Call Beyond Community (Vol. 1). William Carey Library.

Wuryanta, A. E. W. (2004). Digitalisasi Masyarakat: Menilik Kekuatan dan Kelemahan Dinamika Era Informasi Digital dan Masyarakat Informasi. Ilmu Komunikasi, 1(2), 131-142.

Yuliansyah, Y. (2016). Meningkatkan Response Rate Pada Penelitian Survey Suatu Study Literature. Penerbit Change Publications. 